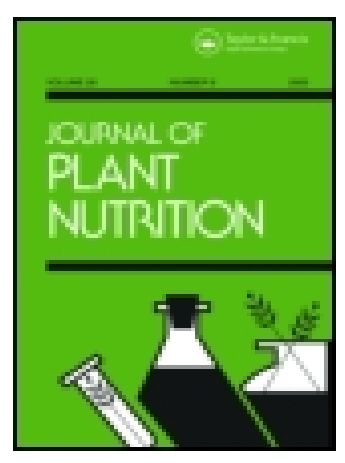

Journal of Plant Nutrition

ISSN: 0190-4167 (Print) 1532-4087 (Online) Journal homepage: http://www.tandfonline.com/loi/lpla20

\title{
Inheritance of iron deficiency chlorosis resistance in groundnut (Arachis hypogaea L.)
}

\section{Santosh K. Pattanashetti, Gopalakrishna K. Naidu, Prakyath Kumar K.V., Omprakash Kumar Singh \& Basavaraj D. Biradar}

To cite this article: Santosh K. Pattanashetti, Gopalakrishna K. Naidu, Prakyath Kumar K.V., Omprakash Kumar Singh \& Basavaraj D. Biradar (2017): Inheritance of iron deficiency chlorosis resistance in groundnut (Arachis hypogaea L.), Journal of Plant Nutrition, DOI: 10.1080/01904167.2017.1384841

To link to this article: http://dx.doi.org/10.1080/01904167.2017.1384841

View supplementary material $₫$

Accepted author version posted online: 28 Sep 2017.

Published online: 28 Sep 2017.

Submit your article to this journal 지

山 Article views: 7

View related articles

View Crossmark data $\nearrow$ 


\title{
Inheritance of iron deficiency chlorosis resistance in groundnut (Arachis hypogaea L.)
}

\author{
Santosh K. Pattanashetti (D) ${ }^{a, b}$, Gopalakrishna K. Naidu ${ }^{a}$, Prakyath Kumar K.V. ${ }^{a}$, \\ Omprakash Kumar Singh ${ }^{\mathrm{a}}$, and Basavaraj D. Biradar ${ }^{\mathrm{a}}$ \\ ${ }^{a}$ Department of Genetics and Plant Breeding, College of Agriculture, Vijayapur, University of Agricultural Sciences, \\ Dharwad, Karnataka, India; ${ }^{\mathrm{b}}$ International Crops Research Institute for the Semi-Arid Tropics, Patancheru, \\ Telangana, India
}

\begin{abstract}
Iron-deficiency chlorosis (IDC) is an important abiotic constraint affecting the growth and yield of groundnut in calcareous and alkaline soils worldwide. The present study investigated the inheritance of IDC resistance among four straight crosses of groundnut involving four IDC susceptible cultivars as females and a common IDC resistant male parent. The $F_{1}$ 's of all the four crosses were resistant to IDC indicating the dominant nature of IDC resistance. The $F_{2}$ 's of all the four crosses showed a good fit to the ratio of 15 (IDC resistant): 1 (IDC susceptible) and their behavior among the $F_{3}{ }^{\prime} s$ was as per the expected ratio of $7: 4: 4: 1$. The IDC resistance in groundnut is under the control of duplicate dominant genes wherein, the presence of a dominant allele at either of the loci results in IDC resistance, while duplicate recessive results in IDC susceptibility. This information would facilitate development of IDC resistant cultivars of groundnut.
\end{abstract}

\section{ARTICLE HISTORY}

Received 23 February 2017

Accepted 6 July 2017

\section{KEYWORDS}

groundnut; genetics; inheritance; iron-deficiency chlorosis (IDC); peanut; resistance

\section{Introduction}

Iron $(\mathrm{Fe})$ is an essential nutrient for all organisms (Zuo and Zhang 2011). In plants, Fe is involved in many physiological processes, including chlorophyll biosynthesis, respiration, and redox reactions (Mimmo et al. 2014; Ye et al. 2015; Zargar et al. 2015). Fe deficiency not only affects the growth and development of plants, but can also lead to anemia in animals and humans (Guerinot and Yi 1994). Iron-deficiency chlorosis (IDC) is common worldwide among crops grown in calcareous, alkaline, coarse textured, eroded and low organic matter containing, and cold region soils because Fe is mostly found in an insoluble form $\left(\mathrm{Fe}^{3+}\right)$. The available form $\left(\mathrm{Fe}^{2+}\right)$ does not exist much in this soil, which makes it less available for uptake by plants in these soils (Ye et al. 2015).

For Fe acquisition from the soils, plants adopt two types of mechanisms (Strategy I and II). StrategyI is found among dicots and monocots, except graminaceous species, which adopt Strategy II. The Strategy I mechanism involves proton release at the rhizosphere that lowers the $\mathrm{pH}$ of soil solution and increasing solubility of $\mathrm{Fe}^{3+}$, $\mathrm{Fe}$ (III) chelate reductase activity that reduces $\mathrm{Fe}^{3+}$ to more soluble $\mathrm{Fe}^{2+}$, and transportation of $\mathrm{Fe}^{2+}$ into the root by metal transporters (Kim and Guerinot 2007). Groundnut (Arachis hypogaea L.) adopts strategy-I type of Fe-acquisition from the soil and its later translocation into plant parts. Groundnut is also found sensitive to Fe deficiency in alkaline and calcareous soils (Zuo and Zhang 2011; Sánchez-Alcalá et al. 2014).

CONTACT Santosh K. Pattanashetti santosh.pattanashetti@gmail.com Department of Genetics and Plant Breeding, College of Agriculture, Vijayapur, University of Agricultural Sciences, 586101, Dharwad, Karnataka, India.

(C) 2017 Taylor \& Francis Group, LLC 
Groundnut is an important food legume grown on $25.7 \mathrm{~m}$ ha area with a production of $42.3 \mathrm{~m} \mathrm{t}$ globally (Faostat 2013). India stands first in groundnut area $(5.20 \mathrm{~m} \mathrm{ha})$ but second in production $(6.56 \mathrm{~m} \mathrm{t})$ after China $(15.78 \mathrm{~m} \mathrm{t})$ due to very less productivity in India $\left(1261 \mathrm{~kg} \mathrm{ha}^{-1}\right)$ compared to China $\left(3491 \mathrm{~kg} \mathrm{ha}^{-1}\right)$ as it is affected by several abiotic and biotic stresses. In India, more than onethird of the soils are calcareous and spread mostly in the low rainfall areas of the western and central parts of the country, where groundnut is a major crop. Hence, IDC is prevalent in Saurashtra region of Gujarat, Marathwada region of Maharashtra, and parts of Rajasthan, Tamil Nadu and Karnataka states in India causing considerable reduction in pod yield (16-32\%) (Singh et al. 1995; Singh 2001). IDC is also a common problem in groundnut-producing areas with calcareous soils in northern China (Gao and Shi 2007) and Pakistan (Imtiaz et al. 2010; Akhtar et al. 2013) causing significant reduction in yield. Severity of IDC will be usually quite high after excessive rainfall and also for groundnut grown under irrigation due to high bicarbonate ion concentration in the rhizosphere (Singh et al. 1995; Zuo et al. 2007).

To counter Fe deficiency in plants, application of Fe fertilizer in the form of inorganic, chelated, and organic formulations have been suggested (Laurie et al. 1991). Application of inorganic-Fe fertilizer to soil is of little benefit as the Fe ionizes and gets converted into insoluble $\mathrm{Fe}^{3+}$ compounds, while foliar application has the problem of poor translocation of applied Fe within the plant (Hüve et al. 2003). Organic-Fe fertilizer is readily adsorbed onto soil particles, which can reduce the fertilizer effect, hence often used in soilless cultivation and as a foliar spray (Cesco et al. 2000; Lucena, Garate, and Villen 2010). Chelated-Fe fertilizer is more expensive and often applied to high-value crops, hence economically not feasible in the semi-arid tropics where groundnut is mainly grown as a rainfed subsistence crop.

Development of micronutrient efficient genotypes can be a successive tool to overcome the micronutrient disorders in soil and also for the improvement in human health (Imtiaz et al. 2010). Genetic variability for IDC response has been reported earlier in groundnut (Samdur et al. 2000; Gao and Shi 2007; Akhtar et al. 2013; Su et al. 2015). It is necessary to understand the inheritance of IDC resistance trait in groundnut towards development of IDC resistant cultivars. Hence, the present study investigates the inheritance of IDC resistance among $\mathrm{F}_{1}, \mathrm{~F}_{2}$ and $\mathrm{F}_{3}$ generations of four crosses of groundnut involving IDC susceptible females (four) and IDC resistant common male parent.

\section{Materials and methods}

\section{Experimental details}

Four straight crosses were generated by involving four released cultivars of groundnut i.e., Dh 86, TAG 24, G 2-52 and GPBD 5 with varying degree of susceptibility to IDC as female parents, while ICGV 86031 as male parent (Table 1) that is resistant to IDC as reported earlier (Dwivedi et al. 1993) as well as based on our previous studies (Boodi, Pattanashetti, and Biradar 2015). All the generations, i.e., parents, $\mathrm{F}_{1}, \mathrm{~F}_{2}, \mathrm{~F}_{2}$-derived $\mathrm{F}_{3}\left(\mathrm{~F}_{2: 3}\right)$ were evaluated in Fe-deficient calcareous soils [diethylenetriaminepentaacetic acid (DTPA) extractable $\mathrm{Fe}\left(\mathrm{Fe}^{2+}\right)<4 \mathrm{mg} \mathrm{kg}^{-1}$ ] in the pot or field studies (Table 2) at College of Agriculture, Vijayapur and assessed for IDC resistance using associated traits like visual chlorotic rating (VCR) and SPAD values at 30,60 and 90 days after sowing (DAS). The soil texture was analyzed by International pipette method (Piper 1966) (Table 2). The soil chemical properties were determined for the following parameters as described by Jackson (1967). The $\mathrm{pH}$ was determined in 1:2.5 soil water suspensions using digital $\mathrm{pH}$ meter [Systronics - 335, india]. The electrical conductivity was determined in 1:2.5 soil water extract using conductivity bridge i.e., digital direct reading conductivity meter [Systronics- 304, india]. The organic carbon content of soil water was determined by Walkley and Black's wet oxidation method. The $\mathrm{CaCO}_{3}$ content in the soil was determined by the acid neutralization method. For estimation of calcium, Tri-ethanol amine solution ( $\mathrm{pH}$ 8.2) was used to extract exchangeable calcium instead of using ammonium acetate to prevent over estimation of calcium in calcareous soil; extracted solution was titrated against versenate (disodium, dihydrogen, ethylene and diamine tetra acetic acid) using murexide as indicator. The available phosphorus (P) was 
Table 1. Pedigree, salient features and IDC response of parents.

\begin{tabular}{|c|c|c|c|c|c|c|}
\hline Parents & $\begin{array}{l}\text { Institute, Year } \\
\text { of Release }\end{array}$ & Pedigree & Features & $\begin{array}{l}\text { Mean } \\
\text { VCR }^{\mathrm{a}}\end{array}$ & $\begin{array}{l}\text { Mean } \\
\text { SPAD }^{\mathrm{a}}\end{array}$ & $\begin{array}{l}\text { IDC } \\
\text { Response }\end{array}$ \\
\hline \multicolumn{7}{|l|}{ Females } \\
\hline Dh 86 & UAS Dharwad, 2005 & Dh-40 $\times$ Dh-8 & $\begin{array}{l}\text { Tolerant to LLS } \\
\text { and sucking pests }\end{array}$ & 3.0 & 19.3 & Susceptible \\
\hline TAG 24 & BARC Mumbai, 1992 & TGS $2 \times$ TGE 1 & $\begin{array}{l}\text { Early maturity, } \\
\text { high harvest index }\end{array}$ & 3.3 & 13.6 & Susceptible \\
\hline G 2-52 & UAS Dharwad, 2015 & EMS mutant of GPBD 4 & $\begin{array}{l}\text { High oil content } \\
\text { and } \mathrm{O} / \mathrm{L} \text { ratio }\end{array}$ & 2.3 & 23.7 & Susceptible \\
\hline GPBD 5 & UAS Dharwad, 2010 & TG $49 \times$ GPBD 4 & $\begin{array}{l}\text { High pod and } \\
\text { kernel yield }\end{array}$ & 3.0 & 16.1 & Susceptible \\
\hline \multicolumn{7}{|l|}{ Male } \\
\hline $\begin{array}{l}\text { ICGV } \\
86031\end{array}$ & $\begin{array}{c}\text { ICRISAT Patancheru, } \\
1991\end{array}$ & $\begin{array}{c}(\mathrm{F} 334 \mathrm{~A}-\mathrm{B}-14 \times \mathrm{NC} \text { Ac 2214) } \\
\mathrm{F}_{2}-\mathrm{B}_{1}-8_{3}-\mathrm{B}_{2}-\mathrm{B}_{3}-\mathrm{B}_{2}-\mathrm{B}_{3}\end{array}$ & $\begin{array}{l}\text { Multiple insect pest resistant; } \\
\text { resistant to bud necrosis } \\
\text { disease and } \\
\text { IDC; photoperiod insensitive }\end{array}$ & 1.0 & 40.8 & Resistant \\
\hline
\end{tabular}

${ }^{a}$ Mean across three stages i.e., 30, 60, 90 days after sowing (DAS)

determined by Olsen's method. Potassium (K) was determined by flame photometer after extracting the soil with neutral normal ammonium acetate. The available sulphur (S) was determined by turbidometric method using $0.15 \% \mathrm{CaCl}_{2}$ as an extractant. The nitrogen $(\mathrm{N})$ content was determined by alkaline potassium permanganate distillation method as described by Subbaiah and Asija (1956) using Kjeldahl flasks. The available Fe (Ferrous, $\left.\mathrm{Fe}^{2+}\right)$, zinc $(\mathrm{Zn})$, manganese $(\mathrm{Mn})$ and copper $(\mathrm{Cu})$ were determined by atomic absorption spectrophotometer after extracting the soil with DTPA (Lindsay and Norvell 1978).

The $\mathrm{F}_{1}$ plants of all the four crosses were raised in pots during summer season of 2013-14. For raising $\mathrm{F}_{1}$ plants, cement pots ( $45 \mathrm{~cm}$ diameter, $45 \mathrm{~cm}$ height) filled with $75 \mathrm{~kg}$ of Fe-deficient calcareous soil obtained from the field (Table 2) was used. In each pot, 3 cross seeds of respective cross were sown in triangular fashion and required number of pots for each $\mathrm{F}_{1}$ 's were used. The recommended dose of

Table 2. Soil texture and chemical properties of the experimental site.

\begin{tabular}{|c|c|}
\hline Parameter & Values \\
\hline \multicolumn{2}{|l|}{ Soil texture $e^{\mathrm{a}}$} \\
\hline Soil type & Shallow black \\
\hline Coarse sand (\%) & 29.1 \\
\hline Fine sand $(\%)$ & 7.1 \\
\hline Silt (\%) & 10.8 \\
\hline Clay $(\%)$ & 40.5 \\
\hline \multicolumn{2}{|l|}{ Soil chemical properties } \\
\hline $\mathrm{pH}$ & 8.33 \\
\hline Electrical conductivity $\left(\mathrm{dsm}^{-1}\right)$ & 0.23 \\
\hline Organic carbon (\%) & 0.25 \\
\hline Available $\mathrm{N}\left(\mathrm{kg} \mathrm{ha}^{-1}\right)$ & 269.7 \\
\hline Available $\mathrm{P}_{2} \mathrm{O}_{5}\left(\mathrm{~kg} \mathrm{ha}^{-1}\right)$ & 45.6 \\
\hline Available $\mathrm{K}_{2} \mathrm{O}\left(\mathrm{kg} \mathrm{ha}^{-1}\right)$ & 296.2 \\
\hline Available $\mathrm{Ca}\left(\mathrm{Cmol}\left(\mathrm{p}^{+}\right) \mathrm{kg}^{-1}\right)$ & 43.7 \\
\hline Available $\mathrm{Mg}\left(\mathrm{Cmol}\left(\mathrm{p}^{+}\right) \mathrm{kg}^{-1}\right)$ & 18.13 \\
\hline Available sulphur ( $\left.\mathrm{mg} \mathrm{kg}^{-1}\right)$ & 7.44 \\
\hline Free lime (\%) & 27.0 \\
\hline Cation exchange capacity $\left(\mathrm{Cmol}\left(\mathrm{p}^{+}\right) \mathrm{kg}^{-1}\right)$ & 95.1 \\
\hline Base saturation (\%) & 67.0 \\
\hline DTPA-extractable $\mathrm{Zn}\left(\mathrm{mg} \mathrm{kg}^{-1}\right)$ & 2.26 \\
\hline DTPA-extractable Fe $\left(\mathrm{mg} \mathrm{kg}^{-1}\right)$ & 3.91 \\
\hline DTPA-extractable Cu $\left(\mathrm{mg} \mathrm{kg}^{-1}\right)$ & 1.97 \\
\hline DTPA-extractable $\mathrm{Mn}\left(\mathrm{mg} \mathrm{kg}^{-1}\right)$ & 2.95 \\
\hline
\end{tabular}

${ }^{\mathrm{a}} 12.5 \%$ difference in total $(\%)$ is due to dissolution of $\mathrm{CaCO}_{3}$ granules during estimation of different soil particles 
$\mathrm{N}\left(25 \mathrm{~kg} \mathrm{ha}^{-1}\right), \mathrm{P}\left(75 \mathrm{~kg} \mathrm{ha}^{-1}\right)$ and $\mathrm{K}\left(25 \mathrm{~kg} \mathrm{ha}^{-1}\right)$ fertilizer were added at the time of sowing, while Fe containing fertilizers were not added. Measured quantity of water was applied equally to all the pots regularly to get the better expression of IDC. The plants were grown in the pot up to harvest (105110 days). All the four $\mathrm{F}_{2}$ populations and respective parents were grown in field having calcareous soil (shallow black, clay texture) (Table 2) during rainy season of 2014 , while $F_{2}$-derived $F_{3}\left(F_{2: 3}\right)$ progenies and respective parents were grown during rainy season of 2015 with an inter and intra-row spacing of $30 \times 10 \mathrm{~cm}$ and row length of $3 \mathrm{~m}$. Required number of rows were used for growing the $\mathrm{F}_{2}$ population and $\mathrm{F}_{2: 3}$ families of all the four crosses. The female and male parents of the respective cross were sown as first and last row flanking $\mathrm{F}_{2}$ population and $\mathrm{F}_{2: 3}$ progenies. The recommended cultivation practices were followed to raise a good crop and protective irrigation was provided under severe moisture stress. All the major nutrients (, $\mathrm{P}$ and $\mathrm{K}$ ) were supplied in the form of urea, diammonium phosphate and muriate of potash fertilizers as per recommended dose. Micronutrients like $\mathrm{Zn}, \mathrm{Mn}$, and $\mathrm{Mg}$ were applied in the form of $\mathrm{ZnSO}_{4}, \mathrm{MnSO}_{4}$ and $\mathrm{MgSO}_{4}$ to avoid the complexity of overlapping deficiency symptoms with Fe. But, fertilizers containing Fe were not applied to maintain the Fe-deficiency status. The plants matured in 105-110 days and were harvested on individual plant basis in $\mathrm{F}_{1}, \mathrm{~F}_{2}$ and $\mathrm{F}_{3}$ generations.

\section{IDC response}

IDC response was assessed based on two related traits, such as VCR and SPAD values. For VCR, the 1-5 scale proposed by Singh and Chaudhari (1993) based on severity and coverage of interveinal chlorosis in entire plant was followed (1) normal green leaves with no chlorosis, (2) green leaves with slight chlorosis on some leaves, (3) moderate chlorosis on several leaves, (4) moderate chlorosis on most of the leaves and (5) severe chlorosis on all the leaves (Figure S1). The chlorophyll meter SPAD 502 (Soil plant analysis development meter, Konica Minolta, india) measures the abssorbance of the leaf in the red and near infrared region. Using these two transmittances, it calculates a numerical SPAD value, which is proportional to the chlorophyll present in the leaf and is negatively related to chlorosis of the plants. The SPAD values were recorded in interveinal area of the standard leaf (third fully opened leaf from the top) of the plants using SPAD 502. Each plant of all the generations (parents, $\mathrm{F}_{1}, \mathrm{~F}_{2}$ and $\mathrm{F}_{2: 3}$ ) of the four crosses were scored for VCR and SPAD values at three different stages i.e., 30, 60 and 90 DAS. Based on the VCR score and SPAD values at most severe stage (at 60 DAS), plants were classified as IDC resistant (VCR 1 to 2 ; SPAD $>25$ ) or susceptible (VCR $>2$ to 5 ; SPAD $<25$ ), respectively.

\section{Statistical analysis}

The observed number of plants showing IDC resistance or susceptibility in $\mathrm{F}_{2}$ and $\mathrm{F}_{2: 3}$ progenies of the four crosses along with expected number of plants or progenies based on predicted phenotypic ratio were subjected to Chi-square $\left(\chi^{2}\right)$ test to assess the goodness of fit of the predicted ratio (Pearson 1900). If the $\chi^{2}$ test was non-significant, the predicted ratio was accepted and probability values were estimated using web resources at http://www.socscistatistics.com/.

\section{Results}

\section{Inheritance of IDC resistance among four crosses of groundnut}

The results pertaining to IDC response of parents, $\mathrm{F}_{1}, \mathrm{~F}_{2}$ and $\mathrm{F}_{2: 3}$ generation plants or progenies among the four crosses and the expected inheritance pattern of IDC resistance among these crosses are presented in this section.

In the cross, Dh $86 \times$ ICGV 86031, all the true $\mathrm{F}_{1}$ plants (12) were IDC resistant with lesser VCR score (1.7) and higher SPAD value (41.9). Segregation in the $\mathrm{F}_{2}$ generation (377 IDC resistant: 21 IDC susceptible) showed a good fit to the predicted ratio of 15:1 (IDC resistant: IDC susceptible) as evident from non-significance of chi-square test $\left(\chi^{2}=0.644, p=0.422\right)$ (Table 3$)$. The $\mathrm{F}_{2}$ derived $\mathrm{F}_{3}$ families 
Table 3. Inheritance of IDC resistance in four crosses of groundnut.

\begin{tabular}{|c|c|c|c|c|c|c|c|c|}
\hline \multirow[t]{2}{*}{ Cross } & \multirow[t]{2}{*}{ Gen. } & \multirow[t]{2}{*}{ No. of Progeny } & \multicolumn{2}{|c|}{ Observed IDC Response } & \multirow[t]{2}{*}{ Predicted Ratio $^{a}$} & \multirow[t]{2}{*}{ Chi-square } & \multirow[t]{2}{*}{ df } & \multirow[t]{2}{*}{ Probability } \\
\hline & & & Resistant & Susceptible & & & & \\
\hline \multirow[t]{7}{*}{ Dh 86 × ICGV 86031} & $\mathrm{~F}_{1}$ & 12 & 12 & - & - & - & - & - \\
\hline & $\mathrm{F}_{2}$ & 12 & 377 & 21 & 15:1 (R:S) & 0.644 & 1 & 0.422 \\
\hline & $\mathrm{F}_{3}$ & 162 & 1084 & 0 & BT (Res) & - & - & - \\
\hline & & 96 & 557 & 177 & $3: 1(\mathrm{R}: S)$ & 0.307 & 1 & 0.580 \\
\hline & & 79 & 1220 & 80 & 15:1 (R:S) & 0.021 & 1 & 0.886 \\
\hline & & 21 & 0 & 104 & BT (Sus) & - & - & - \\
\hline & Total & 358 & - & - & $7: 4: 4: 1$ & 1.973 & 3 & 0.578 \\
\hline \multirow[t]{7}{*}{ TAG $24 \times$ ICGV 86031} & $\mathrm{~F}_{1}$ & 3 & 3 & - & - & - & - & - \\
\hline & $\mathrm{F}_{2}$ & 3 & 106 & 6 & $15: 1$ & 0.152 & 1 & 0.696 \\
\hline & $\mathrm{F}_{3}$ & 44 & 345 & 0 & BT (Res) & - & - & - \\
\hline & & 25 & 191 & 52 & $3: 1$ (R:S) & 1.680 & 1 & 0.195 \\
\hline & & 20 & 318 & 20 & $15: 1(R: S)$ & 0.064 & 1 & 0.800 \\
\hline & & 6 & 0 & 59 & BT (Sus) & - & - & - \\
\hline & Total & 95 & - & - & $7: 4: 4: 1$ & 0.802 & 3 & 0.849 \\
\hline \multirow[t]{7}{*}{ GPBD $5 \times$ ICGV 86031} & $\mathrm{~F}_{1}$ & 1 & 1 & - & - & - & - & - \\
\hline & $\mathrm{F}_{2}$ & 1 & 67 & 4 & $15: 1$ & 0.046 & 1 & 0.830 \\
\hline & $\mathrm{F}_{3}$ & 22 & 124 & 0 & BT (Res) & - & - & - \\
\hline & & 17 & 93 & 24 & $3: 1$ (R:S) & 1.256 & 1 & 0.262 \\
\hline & & 13 & 207 & 13 & $15: 1(R: S)$ & 0.044 & 1 & 0.835 \\
\hline & & 3 & 0 & 12 & BT (Sus) & - & - & - \\
\hline & Total & 55 & - & - & $7: 4: 4: 1$ & 1.042 & 3 & 0.791 \\
\hline \multirow[t]{7}{*}{ G 2-52 × ICGV 86031} & $\mathrm{~F}_{1}$ & 3 & 3 & - & - & - & - & - \\
\hline & & 3 & 38 & 2 & $15: 1$ & 0.107 & 1 & 0.744 \\
\hline & $\mathrm{F}_{3}$ & 12 & 36 & 0 & BT (Res) & - & - & - \\
\hline & & 8 & 65 & 20 & 3:1 (R:S) & 0.098 & 1 & 0.754 \\
\hline & & 5 & 80 & 5 & $15: 1$ (R:S) & 0.020 & 1 & 0.889 \\
\hline & & 2 & 0 & 15 & BT (Sus) & - & - & - \\
\hline & Total & 27 & - & - & $7: 4: 4: 1$ & 0.746 & 3 & 0.862 \\
\hline
\end{tabular}

Gen. - Generation; df - Degrees of freedom; R - IDC Resistant; S - IDC Susceptible; BTR - Breeding True for IDC Resistance; BTS Breeding True for IDC Susceptibility

${ }^{a}$ F2 ratio - 15 (IDC Resistant): 1 (IDC Susceptible); $F_{2: 3}$ ratio - 7 (BTR): 4 (3R:1S): 4 (15R:1S): 1 (BTS)

$\left(\mathrm{F}_{2: 3}\right)$ (358) also showed a good fit to the expected ratio of 7:4:4:1 i.e., Breeding true for IDC resistance (BTR): 3:1 (IDC Resistant: IDC Susceptible): 15:1 (IDC Resistant: IDC Susceptible): Breeding true for IDC susceptibility (BTS) based on the non-significance of chi-square test $\left(\chi^{2}=1.973\right.$, $p=0.578$.

All the $\mathrm{F}_{1}$ plants (3) in the cross, TAG $24 \times$ ICGV 86031 were IDC resistant with lesser VCR (1.6) and higher SPAD value (36.6). Segregation in the $\mathrm{F}_{2}$ generation (106 IDC resistant: 6 IDC susceptible) was in accordance with the predicted ratio of 15:1 (IDC resistant: IDC susceptible) based on the nonsignificance of chi-square test $\left(\chi^{2}=0.152, p=0.696\right)$ (Table 3). The $\mathrm{F}_{2: 3}$ families (95) showed a good fit to the predicted ratio of 7:4:4:1 [BTR : (3R:1S) : (15R:1S) : BTS] as described for previous cross based on the non-significance of chi-square test $\left(\chi^{2}=0.802, p=0.849\right)$.

The only $\mathrm{F}_{1}$ plant recovered from the cross, GPBD $5 \times$ ICGV 86031 was IDC resistant with lesser VCR (1.3) and higher SPAD value (36.9). Segregation in the $\mathrm{F}_{2}$ generation (67 IDC resistant: 4 IDC susceptible) was in agreement with the predicted ratio of 15:1 (IDC resistant: IDC susceptible) based on the non-significance of chi-square test $\left(\chi^{2}=0.046, p=0.830\right)$ (Table 3). The $\mathrm{F}_{2: 3}$ families (55) also showed a good fit to the predicted ratio of 7:4:4:1 [BTR : (3R:1S) : (15R:1S) : BTS] evident from the non-significance of chi-square test $\left(\chi^{2}=1.042, p=0.791\right)$.

All the $F_{1}$ plants (3) of the cross, G 2-52 × ICGV 86031 were also IDC resistant with lesser VCR (1.6) and higher SPAD value (36). Segregation in the $F_{2}$ generation (38 IDC resistant: 2 IDC susceptible) was in agreement with the predicted ratio of 15:1 (IDC resistant: IDC susceptible) based on the non-significance of chi-square test $\left(\chi^{2}=0.107, p=0.744\right)$ (Table 3). The $F_{2: 3}$ families (27) also showed a good fit to the predicted ratio of 7:4:4:1 [BTR : (3R:1S) : (15R:1S) : BTS] evident from the non-significance of chi-square test $\left(\chi^{2}=0.746, p=0.862\right)$. 


\section{Discussion}

\section{Phenotyping for IDC response}

The VCR and chlorophyll content estimation are widely used for selecting IDC resistant groundnut genotypes in the field (Gao and Shi 2007; Samdur et al. 1999). The utility of SPAD chlorophyll meter for rapid and in situ screening of genotypes for IDC resistance has been evident from significant positive correlation between SPAD readings and chlorophyll content observed earlier (Samdur et al. 2000). Hence, in the present study, VCR and SPAD readings were used to phenotype the IDC response of parents, $\mathrm{F}_{1}, \mathrm{~F}_{2}$, and $\mathrm{F}_{2: 3}$ generation plants or progenies at three different stages (30,60 and $90 \mathrm{DAS}$ ). Since, the most severe symptoms were observed at 60 DAS, the same data was used to classify the plants as IDC resistant (VCR 1 to 2 ; SPAD $>25$ ) or susceptible (VCR $>2$ to 5; SPAD $<25$ ). Gao, Shi, and Zhou (2009) also observed highest chlorosis scores for susceptible cultivars during 50-65 days after emergence as noted in this study.

\section{Inheritance of IDC resistance}

The $\mathrm{F}_{1}$ 's of all the four crosses were resistant to IDC, which indicate that IDC resistance is a dominant trait in groundnut. The segregation in the $\mathrm{F}_{2}$ and $\mathrm{F}_{2: 3}$ generations of all the four crosses suggest that IDC resistance is under the control of duplicate dominant genes (A and $B$ ) wherein, the presence of a dominant allele at either of the loci (A_B_, A_bb, aaB_) results in IDC resistance, while duplicate recessive (aabb) results in IDC susceptibility. Earlier in groundnut, Fe absorption efficiency has been suggested to be governed by a basic gene with two or four inhibitory complementary genes showing $\mathrm{F}_{2}$ ratios of 21 efficient: 43 inefficient, and 525 efficient: 499 inefficient wherein, the trait is governed by a dominant basic gene but presence of dominant inhibitory genes make them inefficient (Gowda et al. 1993). Using six generation mean analysis, Samdur, Manivel, and Mathur (2005) studied the genetic basis of IDC resistance in groundnut in the cross ICGV $86030 \times$ ICGV 86031. The $\mathrm{F}_{1}$ mean was significantly higher than the mid-parental and better parental values for carotenoids, indicating the dominance of this character; Out of four scaling tests, at least two were found significant for all the related characters indicating the presence of non-allelic interactions for their inheritance. Six-parameter model indicated the presence of significant additive $\times$ dominance epistatic interaction for chlorophyll $a$, chlorophyll $b$, and total chlorophyll at both 35 and 50 days after emergence. These reports support the dominance nature of the IDC resistance trait in groundnut as noted in this study.

This is the first study wherein inheritance of IDC resistance in groundnut has been elucidated based on behavior in the $\mathrm{F}_{2}$ and $\mathrm{F}_{3}$ generations. The results indicated duplicate dominant genes governing of IDC resistance in groundnut. Several traits in groundnut are found to be governed by duplicate or multiple genes due to allotetraploid nature consisting of two genomes viz., A and B, which are genetically similar (Hammons 1973; Wynne and Coffelt 1982; Kochert et al. 1991). In addition, IDC resistance or Fe absorption efficiency has been reported to be governed by one or two dominant genes in several legumes like soybean (Weiss 1943), dry beans (Coyne et al. 1982), mungbean (Srinives et al. 2010), chickpea (Toker et al. 2010) and lentils (Ali, Riaz-ul-haque, and Bhatti 1997). IDC resistance has also been suggested to be polygenically inherited with additive effect in soybean (Cianzio and Fehr 1982) and tomato (Dasgan et al. 2004).

In groundnut, high correlations observed between root Fe reduction and field chlorosis scores suggested that Fe-reduction capacity as a better physiological indicator for screening Fe-efficient genotypes (Gao and Shi 2007). In addition, the soil or foliar application of sodium nitroprusside, a NO donor has shown to increase the available $\mathrm{Fe}$ in the soil by reducing the $\mathrm{pH}$ of the soil, increase the $\mathrm{H}^{+}$-ATPase and $\mathrm{Fe}^{3+}$ reductase activities, increase the total $\mathrm{Fe}$ concentration in the leaves and antioxidant activities in groundnut (Kong et al. 2014). In the light of this, the physiological basis of IDC resistance in the parent ICGV 86031 need to be established through further detailed studies, such as change in the $\mathrm{pH}, \mathrm{Fe}-$ reduction capacity and translocation efficiency.

The Fe-efficient genotypes able to respond to the Fe-limited condition and delay the onset or minimize the impact of IDC, whereas the inefficient genotypes respond slow or lack the ability to respond. 
The genes and gene families that are involved in Fe uptake under Fe-deficient conditions have been identified and further characterized in Arabiopsis and other crop species (Kim and Guerinot 2007). In peanut, Fe responsive genes such as AhIRT1, encoding an Fe-uptake transporter (Ding et al. 2010); $A h F R O 1$, encoding ferric-chelate reductase (Ding et al. 2009), and; AhNRAMP1, encoding a functional Fe transporter (Xiong et al. 2012) have been identified. Hence, it is necessary to investigate the role of these identified genes and also homologues of other genes to understand the basis of IDC resistance in ICGV 86031. Molecular markers significantly associated with IDC resistance genes have been identified in soybean (Charlson, Cianzio, and Shoemaker 2003) and mungbean (Srinives et al. 2010). We are developing recombinant inbred populations from the crosses used in this study; further mapping using these populations would be helpful in identification of genomic regions and tightly linked markers associated with IDC resistance and further genomics assisted improvement of IDC resistance in groundnut in particular and legumes in general.

\section{Conclusions}

The inheritance of IDC resistance among four straight crosses of groundnut indicated the dominant nature of the trait as all the $F_{1}$ 's were IDC resistant. The segregation in the $F_{2}$ and $F_{2: 3}$ generations of all the four crosses suggested that IDC resistance is under the control of duplicate dominant genes. This information would be useful towards development of IDC-resistant cultivars of groundnut in particular and legumes in general.

\section{Acknowledgments}

This research was planned and executed by authors Pattanashetti, Naidu and Biradar; data was generated as part of the post-graduation research program of Prakyath Kumar and Omprakash Kumar at Department of Genetics and Plant Breeding, College of Agriculture, Vijayapur under University of Agricultural Sciences, Dharwad; data was interpreted and manuscript was prepared by Pattanashetti and Naidu.

\section{ORCID}

Santosh K. Pattanashetti (iD http://orcid.org/0000-0001-9869-081X

\section{References}

Akhtar, S., A. Shahzad, M. Arshad, and Fayyaz-Ul-Hassan. 2013. Morpho-physiological evaluation of groundnut (Arachis hypogaea L.) genotypes for iron deficiency tolerance. Pakistan Journal of Botany 45 (3):893-9.

Ali, A., M. Riaz-ul-haque, and M. S. Bhatti. 1997. Inheritance of resistance to iron-deficiency chlorosis in lentil. Lens Newsletter 24:28-9.

Boodi, I. H., S. K. Pattanashetti, and B. D. Biradar. 2015. Identification of groundnut genotypes resistant to iron deficiency chlorosis. Karnataka Journal of Agricultural Sciences 28 (3):406-8.

Cesco, S., V. Romheld, Z. Varanini, and R. Pinton. 2000. Solubilization of iron by water-extractable humic substances. Journal of Plant Nutrition and Soil Science 163:285-90. doi:10.1002/1522-2624(200006)163:3<285::AIDJPLN285>3.0.CO;2-Z.

Charlson, D. V., S. R. Cianzio, and R. C. Shoemaker. 2003. Associating SSR markers with soybean resistance to iron deficiency chlorosis. Journal of Plant Nutrition 26 (10):2267-76. doi:10.1081/PLN-120024280.

Cianzio, S. R., and W. R. Fehr. 1982. Variation in the inheritance of resistance to iron deficiency chlorosis in soybeans. Crop Science 22:433-4. doi:10.2135/cropsci1982.0011183X002200020055x.

Coyne, D. P., S. S. Korban, D. Knudsen, and R. B. Clark. 1982. Inheritance of iron deficiency in crosses of dry beans. Journal Plant Nutrition 5:575-85. doi:10.1080/01904168209362985.

Dasgan, H. Y., K. Abak, I. Cakmak, V. Römheld, and S. Sensoy. 2004. Inheritance of tolerance to leaf iron deficiency chlorosis in tomato. Euphytica 139 (1):51-7. doi:10.1007/s10681-004-2033-6.

Ding, H., L. Duan, H. Wu, R. Yang, H. Ling, W. X. Li, and F. Zhang. 2009. Regulation of AhFRO1, an Fe(III)-chelate reductase of peanut, during iron deficiency stress and intercropping with maize. Physiologia Plantarum 136:274-83. doi:10.1111/j.1399-3054.2009.01219.x. 
Ding, H., L. H. Duan, F. Li, H. F. Yan, M. Zhao, F. S. Zhang, and W. X. Li. 2010. Cloning and functional analysis of the peanut iron transporter AhIRT1 during iron deficiency stress and intercropping with maize. Journal of Plant Physiology 167:996-1002. doi:10.1016/j.jplph.2009.12.019

Dwivedi, S. L., D. V. R. Reddy, S. N. Nigam, G. V. R. Rao, J. A. Wightman, P. W. Amin, G. V. S. Nagabhushanam, A. S. Reddy, E. Scholberg, and V. M. Ramraj. 1993. Registration of ICGV 86031 peanut germplasm. Crop Science 33 (1):220. doi:10.2135/cropsci1993.0011183X003300010069x.

Faostat. 2013. Accessed 07 February, 2017. http://faostat3.fao.org.

Gao, L., and Y. X. Shi. 2007. Genetic differences in resistance to iron deficiency chlorosis in peanut. Journal of Plant Nutrition 30 (1-3):37-52. doi:10.1080/01904160601054965.

Gao, L., Y. X. Shi, and J. M. Zhou. 2009. Study on the sensitive period and screening index for iron deficiency chlorosis in peanut. Plant Nutrition and Fertilizer Science 15 (4):917-22.

Gowda, M. V. C., V. N. Kulkarni, H. L. Nadaf, and A. F. Habib. 1993. Inheritance of iron absorption efficiency in groundnut. Crop Improvement 20:197-200.

Guerinot, M. L., and Y. Yi. 1994. Iron: Nutritious, noxious and not readily available. Plant Physiology 104:815-20. https:// www.ncbi.nlm.nih.gov/pmc/articles/PMC160677/pdf/1040815.pdf

Hammons, R. O. 1973. Genetics of Arachis hypogaea. In Peanuts: Culture and Uses, 135-73. Stillwater, United Kingdom: American Peanut Research Education Association.

Hüve, K., R. Remus, D. Lüttschwager, and W. Merbach. 2003. Transport of foliar-applied iron $\left({ }^{59} \mathrm{Fe}\right)$ in Vicia faba. Journal of Plant Nutrition 26 (10-11):2231-42. doi:10.1081/PLN-120024277.

Imtiaz, M., A. Rashid, P. Khan, M. Y. Memon, and M. Aslam. 2010. The role of micronutrients in crop production and human health. Pakistan Journal of Botany 42 (4):2565-78.

Jackson, M. L. 1967. Soil chemical analysis. New Delhi: Prentice Hall of India Private Limited.

Kim, S. A., and M. L. Guerinot. 2007. Mining iron: Iron uptake and transport in plants. FEBS Letters 581 (12):2273-80. doi:10.1016/j.febslet.2007.04.043.

Kochert, G., T. Halward, W. D. Branch, and C. E. Simpson. 1991. RFLP variability in peanut (Arachis hypogaea L.) cultivars and wild species. Theoretical and Applied Genetics 81:565-70. doi:10.1007/BF00226719.

Kong, J., Y. Donga, L. Xua, S. Liua, and X. Bai. 2014. Role of exogenous nitric oxide in alleviating iron deficiency-induced peanut chlorosis on calcareous soil. Journal of Plant Interactions 9 (1):450-9. doi:10.1080/17429145.2013.853327.

Laurie, S. H., N. P. Tancock, S. P. Mcgrath, and J. R. Sanders. 1991. Influence of complexation on the uptake by plants of iron, manganese, copper and zinc. Journal of Experimental Botany 42:509-13. doi:10.1093/jxb/42.4.515.

Lindsay, W. L., and W. A. Norvell. 1978. Development of a DTPA soil test for zinc, iron, manganese, and copper. Soil Science Society of America Journal 42:421-8. doi:10.2136/sssaj1978.03615995004200030009x.

Lucena, J. J., A. Garate, and M. Villen. 2010. Stability in solution and reactivity with soils and soil components of iron and zinc complexes. Journal of Plant Nutrition and Soil Science 173:900-6. doi:10.1002/jpln.200900154.

Mimmo, T., D. Del Buono, R. Terzano, N. Tomasi, G. Vigani, C. Crecchio, R. Pinton, G. Zocchi, and S. Cesco. 2014. Rhizospheric organic compounds in the soil-microorganism-plant system: Their role in iron availability. European Journal of Soil Science 65:629-42. doi:10.1111/ejss.12158.

Pearson, K., 1900. On the criterion that a given system of deviations from the probable in the case of correlated system of variables is such that it can be reasonably supposed to have arisen from random sampling. Philosophical Magazine Series 550 (302):157-75. doi:10.1080/14786440009463897.

Piper, C. S. 1966. Soil and Plant Analysis. Bombay: Hans Publisher.

Samdur, M. Y., R. K. Mathur, P. Manivel, A. L. Singh, A. Bandyopadhyay, and B. M. Chikani. 1999. Screening of some advanced breeding lines of groundnut (Arachis hypogaea) for tolerance of lime-induced iron-deficiency chlorosis. Indian Journal of Agricultural Sciences 69 (10):722-5.

Samdur, M. Y., A. L. Singh, R. K. Mathur, P. Manivel, B. M. Chikani, H. K. Gor, and M. A. Khan. 2000. Field evaluation of chlorophyll meter for screening groundnut (Arachis hypogaea L.) genotypes tolerant to iron-deficiency chlorosis. Current Science 79 (2):211-4. http://www.iisc.ernet.in/currsci/jul252000/Samdur.pdf

Samdur, M. Y., P. Manivel, and R. K. Mathur. 2005. Genetics of iron-chlorosis related characters in groundnut, Arachis hypogaea L. Journal of Oilseeds Research 22 (1):162-3.

Sánchez-Alcalá, I., M. D. del Campillo, V. Barrón, and J. Torrent. 2014. Evaluation of preflooding effects on iron extractability and phytoavailability in highly calcareous soil in containers. Journal of Plant Nutrition and Soil Science 177:150-8. doi:10.1002/jpln.201200302.

Singh, A. L., 2001. Yield losses in groundnut due to micronutrient deficiencies in calcareous soils of India. In Plant nutrition: food security and sustainability of agro-ecosystems through basic and applied research, 838-9. eds. W. J. Horst, M. K. Schenk, A. Burkert, N. Claassen, H. Flessa, W. B. Frommer, H. Goldbach, H. W. Olfs, V. Romheld, Hannover, Germany: 14th International Plant Nutrition Colloquium.

Singh, A. L., and V. Chaudhari. 1993. Screening of groundnut germplasm collection and selection of genotypes tolerant of lime-induced iron-chlorosis. Journal of Agriculture Sciences (Cambridge) 121:205-11. doi:10.1017/ S0021859600077078.

Singh, A. L., V. Chaudhari, V. G. Koradia, and P. V. Zala. 1995. Effect of excess irrigation and iron and sulphur fertilizers on the chlorosis, dry matter production, yield and nutrients uptake by groundnut in calcareous oil. Agrochimica 39 (4):184-98. 
Srinives, P. Kitsanachandee, C. Ratanakorn, T. Sommanas, and W. Chanprame. 2010. Inheritance of resistance to iron deficiency and identification of AFLP markers associated with the resistance in mungbean [Vigna radiata (L.) Wilczek]. Plant and Soil 335 (1/2):423-37. doi:10.1007/s11104-010-0431-1.

Su, Y., Z. Zhang, G. Su, J. Liu, C. Liu, and G. Shi. 2015. Genotypic differences in spectral and photosynthetic response of peanut to iron deficiency. Journal of Plant Nutrition 38 (1):145-60. doi:10.1080/01904167.2014.920392.

Subbaiah, G. V., and C. L. Asija. 1956. Soil fertility evaluation to serve Indian farmers. Mysore: Department of Agriculture.

Toker, C., T. Yildirim, H. Canci, N. E. Inci, and F. O. Ceylan. 2010. Inheritance of resistance to iron deficiency chlorosis in chickpea (Cicer arietinum L.). Journal of Plant Nutrition 33:1366-73. doi:10.1080/01904167.2010.484096.

Wynne, J. C., and T. A. Coffelt. 1982. Genetics of Arachis. In Peanut Science and Technology, 50-94. eds. H. E., Pattee and C. T., Young, Yoakum, Texas, USA: American Peanut Research Education Society.

Weiss, M. G. 1943. Inheritance and physiology of efficiency in iron utilization in soybeans. Genetics 28:253-68. https:// www.ncbi.nlm.nih.gov/pmc/articles/PMC1209208/pdf/253.pdf

Xiong, H., T. Kobayashi, Y. Kakei, T. Senoura, M. Nakazono, H. Takahashi, H. Nakanishi, H. Shen, P. Duan, X. Guo, N. K. Nishizawa, and Y. Zuo. 2012. AhNRAMP1 iron transporter is involved in iron acquisition in peanut. Journal of Experimental Botany 63 (12):4437-46. doi:10.1093/jxb/ers117.

Ye, L. X., L. Li, L.Wang, S. Wang, S. Li, J. Du, S. Zhang, and H. Shou. 2015. MPK3/MPK6 are involved in iron deficiencyinduced ethylene production in Arabidopsis. Frontiers in Plant Science 6:953. doi:10.3389/fpls.2015.00953.

Zargar, S. M., G. K. Agrawal, R. Rakwal, and Y. Fukao. 2015. Quantitative proteomics reveals role of sugar in decreasing photosynthetic activity due to Fe deficiency. Frontiers in Plant Science 6:592. doi:10.3389/fpls.2015.00592.

Zuo, Y., L. Ren, F. Zhang, and R. F. Jiang. 2007. Bicarbonate concentration as affected by soil water content controls iron nutrition of peanut plants in a calcareous soil. Plant Physiology and Biochemistry 45 (5):357-64. doi:10.1016/j. plaphy.2007.03.017.

Zuo, Y. M., and F. S. Zhang. 2011. Soil and crop management strategies to prevent iron deficiency in crops. Plant and Soil 339:83-95. doi:10.1007/s11104-010-0566-0. 